Open Journal of Language and Linguistics
(DOI:10.28933/OJLL)

\title{
A clinical approach of medicinal therapies in Alzheimer's disease
}

\author{
Oliveira E. F. S ${ }^{1}$; Silva A. C. M; Silva G. K. A ${ }^{1}$, Torres G. S. S ${ }^{1}$; Silva V. P. B ${ }^{1}$. Cordeiro R. P ${ }^{2}$.
}

${ }^{1}$ Pharmacy students of the Academic Center Tabosa de Almeida - Asces-Unita, Caruaru$\mathrm{PE},{ }^{2}$ University Professor of the Academic Center Tabosa de Almeida - Asces-Unita, Caruaru-PE.

\begin{abstract}
Background: Alzheimer's disease (AD) accounts for 50 to $70 \%$ of dementias in people over 65 years. It is a neurodegenerative disease, characterized by progressive disorder of memory and other psychological functions, affecting the social life of the patient. However, although it has been studied for years, the actual cause is not known as there is no single diagnosis for this disease and there is no specific standard for its treatment. Aim: To identify the pharmacological groups and drugs most used in the treatment of AD. Methods: Review of published researches from 2010 to 2017 in the Google Scholar, Scielo and Bireme databases, using the descriptors Alzheimer's disease and Pharmacology. Results: In $A D$ there is a formation of senile plaques produced by the undue accumulation of $\beta$-amyloid protein, promoting a neuronal degeneration. Therefore, the drugs of first choice for treatment are cholinesterase inhibitors and the most commonly used drugs are donezepil, galantamine and rivastigmine. Discussion: Donezepil causes improvement in cognitive function and stabilization of the patient's functional capacity. Galantamine and rivastigmine inhibit the enzyme acetylcholinesterase and act directly on the presynaptic nicotinic receptors, causing an improvement in cognitive function, also in memory and mood. There are no significant differences in efficacy between the three most commonly used drugs and the side effects are few in both. Conclusion: Pharmacological treatment is capable of promoting the improvement of the cognitive symptoms of $A D$, not being able to cure or paralyze the degeneration of nerve cells, but allowing it to progress slow${ }^{*}$ Correspondence to Author: Oliveira E. F. S

Academic Center Tabosa de Almeida - Asces-Unita, Caruaru-PE

How to cite this article:

Oliveira E. F. S ; Silva A. C. M; Silva G. K. A, Torres G. S. S ; Silva V. P. B. Cordeiro R. P.A clinical approach of medicinal therapies in Alzheimer's disease.Open Journal of Language and Linguistics, 2018, $1: 5$ ly. Therefore, there is a need for greater investment in research to discover new therapies, given that this disease is increasing.

Keywords: Alzheimer's disease; Degenerative Disease; Pharmacology
\end{abstract}

